\title{
Renal function studies after nephrectomy in renal donors
}

\author{
J M DAVISON, P R ULDALL, J WALLS
}

\section{Summary}

Two to six years after they had donated a kidney the 24-hour creatinine clearances of five women and four men had recovered to $85 \%$ and $87 \%$ respectively of prenephrectomy performance. The male donors had a lower 24-hour creatinine clearance than age-matched controls, but during dextrose and inulin infusion they had similar values for inulin clearance, creatinine clearance, and glucose reabsorption. By contrast, the female donors had significantly reduced clearances both over 24 hours and during infusion, as well as impaired ability to reabsorb glucose. This suggests that potential female donors should be more vigorously investigated before nephrectomy.

\section{Introduction}

Renal plasma flow (RPF) and glomerular filtration rate (GFR) increase considerably in early pregnancy to values $50-100 \%$ above the pre-pregnancy levels. ${ }^{2}$ This is not accompanied by an equal capacity on the part of the proximal tubule to reabsorb glucose from the glomerular filtrate, which often results in conspicuous glycosuria. In some women this relative inability to reabsorb glucose is exaggerated during glucose infusion and the phenomenon persists after pregnancy, though the 24-hour urinary excretion of glucose reverts to normal. It has been suggested that women with definite glycosuria during pregnancy, and those with an impaired ability to reabsorb glucose during infusions, may have suffered minor degrees of renal damage from urinary tract infection during childhood or adolescence, for example, with previous asymptomatic bacteriuria. ${ }^{3}$

Impaired glucose reabsorption may occur after removal of a kidney in a healthy donor because of the "strain" placed on the remaining kidney. In donors the RPF and GFR of the remaining kidney increase from half the preoperative level to an average of $70-80 \%$ of the "two-kidney" petformance. ${ }^{4}$ Moreover, a removed kidney improves its performance when transplanted into the recipient by about the same amount, ${ }^{6}$ - which suggests that the kidney's ability to adapt is innate and not dependent on the maintenance of an undisturbed environment.

A rise in GFR (either in a single kidney after contralateral nephrectomy or in a pair of kidneys in early pregnancy) requires a commensurate increase in the ability of the tubular system to deal with the filtrate if normal renal physiology is to be maintained. It is believed that the restoration of "glomerulotubular balance" " necessitates hypertrophy and hyperplasia of tubule cells, but little is known about the functional aspects of such tubular changes.

MRC Reproduction and Growth Unit, Princess Mary Maternity Hospital, Newcastle upon Tyne NE2 3BD

J M DAVISON, MB, MRCOG, scientific staff

Department of Medicine, Royal Victoria Infirmary, Newcastle upon Tyne NE1 4LP

P R ULDALL, MD, FRCP, consultant physician (present address : Division of Nephrology, Toronto Western Hospital, Toronto)

J WALLS, MB, MRCP, lecturer (present address: Leicester General Hospital, Leicester)
It seemed logical to re-examine tubular reabsorption of glucose by modern techniques to study the changes, if any, in "glomerulotubular balance" in healthy male and female donors. Agematched healthy men and women with both kidneys intact were studied as controls.

\section{Subjects and methods}

Five women, aged 36-56 years, and four men, aged 48-58 years, who had donated a kidney two to six years earlier were compared with a control group of five women aged 35-52 and four men aged 47-54; further details are given in table I. All subjects gave informed consent to the procedure. They were in excellent general health with no history or evidence of renal disease. Midstream specimens of urine were sterile on aerobic and anaerobic culture in all cases.

\begin{tabular}{|c|c|c|c|c|c|c|}
\hline & & $\begin{array}{c}\text { Subject } \\
\text { No }\end{array}$ & Age & $\begin{array}{c}\text { Height } \\
(\mathrm{cm})\end{array}$ & $\underset{\text { (kg) }}{\text { Weight }}$ & Parity \\
\hline Male donors.. & $\ldots$ & $\begin{array}{l}1 \\
2 \\
3 \\
4\end{array}$ & $\begin{array}{l}58 \\
57 \\
54 \\
48\end{array}$ & $\begin{array}{l}181 \\
167 \\
168 \\
166\end{array}$ & $\begin{array}{l}86.6 \\
76.9 \\
79.6 \\
70.5\end{array}$ & \\
\hline Female donors & .. & $\begin{array}{l}5 \\
6 \\
7 \\
8 \\
9\end{array}$ & $\begin{array}{l}56 \\
50 \\
48 \\
42 \\
36\end{array}$ & $\begin{array}{l}159 \\
150 \\
166 \\
168 \\
167\end{array}$ & $\begin{array}{l}55 \cdot 6 \\
58 \cdot 9 \\
80 \cdot 8 \\
66 \cdot 9 \\
64 \cdot 0\end{array}$ & $\begin{array}{l}2+0 \\
2+0 \\
2+0 \\
3+0 \\
0+0\end{array}$ \\
\hline Male controls & $\ldots$ & $\begin{array}{l}10 \\
11 \\
12 \\
13\end{array}$ & $\begin{array}{l}54 \\
51 \\
49 \\
47\end{array}$ & $\begin{array}{l}166 \\
178 \\
180 \\
172\end{array}$ & $\begin{array}{l}80 \cdot 7 \\
80 \cdot 0 \\
88 \cdot 1 \\
72 \cdot 5\end{array}$ & \\
\hline Female controls & $\ldots$ & $\begin{array}{l}14 \\
15 \\
16 \\
17 \\
18\end{array}$ & $\begin{array}{l}52 \\
50 \\
49 \\
37 \\
35\end{array}$ & $\begin{array}{l}163 \\
163 \\
155 \\
165 \\
168\end{array}$ & $\begin{array}{l}64 \cdot 9 \\
76 \cdot 0 \\
56 \cdot 0 \\
61 \cdot 0 \\
62 \cdot 7\end{array}$ & $\begin{array}{l}3+0 \\
1+0 \\
2+0 \\
3+0 \\
0+0\end{array}$ \\
\hline
\end{tabular}

A standard dextrose and inulin intravenous infusion, based on that described by Goldring and Chasis, ${ }^{8}$ was administered ${ }^{9}$ using a constant infusion pump. The subjects were comfortably seated in an upright position throughout the infusion. Stable plasma levels of inulin of about $300 \mathrm{mg} / 1$ were achieved after 30 minutes; plateau plasma glucose levels of $8 \cdot 34-16 \cdot 7 \mathrm{mmol} / 1(150-300 \mathrm{mg} / 100 \mathrm{ml})$ were usually achieved (see table III). After the initial 30 minutes clearances were estimated for three successive 20 minute periods. The subjects passed urine spontaneously, the women using a commode beside the chair. Because of the diuretic effect of the infused glucose, and because the subjects were encouraged to drink during the infusion, urine volumes were large and therefore errors of collection due to incomplete bladder emptying were unlikely to be significant. Before the infusion all subjects collected urine for the estimation of creatinine and glucose during the preceding 24 hours. A blood sample was taken within that 24 hours for plasma creatinine determination.

Inulin concentrations in both plasma and urine were determined by the method of Heyrovsky, ${ }^{10}$ and we took particular care to prevent precipitation of inulin from the urine by collecting samples into a warmed container and keeping them warm until diluted in the laboratory. "True" creatinine was determined in both plasma and urine by a kinetic method ${ }^{12}$ using an LKB 1800 reaction rate analyser to obviate any confusion with non-creatinine chromogens. Glucose in urine was determined by the hexokinase-glucose-6-phosphate dehydrogenase method, ${ }^{13} 14$ and in plasma by a glucose oxidase-peroxidase method. ${ }^{15}$

\section{Results}

Data are presented without correction to a standard body surface area of $1.73 \mathrm{~m}^{2}$. The progressive change in 24-hour creatinine clearance from before nephrectomy to one week after and two to six years 
TABLE II-GFR (24-hour creatinine clearance) in nine healthy donors

\begin{tabular}{|c|c|c|c|}
\hline \multirow{2}{*}{ Subject No } & \multirow{2}{*}{ Before operation } & \multicolumn{2}{|c|}{ After operation } \\
\hline & & at 1 week & at $(x)$ years* \\
\hline \multicolumn{4}{|c|}{ Men } \\
\hline $\begin{array}{l}1 \\
2 \\
3 \\
4\end{array}$ & $\begin{array}{r}104 \\
80 \\
111 \\
109\end{array}$ & $\begin{array}{l}79 \\
74 \\
74 \\
47\end{array}$ & $\begin{array}{l}84(3) \\
81(6) \\
97(2) \\
89(4)\end{array}$ \\
\hline Mean ( $\quad$ SD) & $101 \cdot 0+14 \cdot 3$ & $68 \cdot 5 \div 14.5$ & $87 \cdot 8+6.99$ \\
\hline \multicolumn{4}{|c|}{ Women } \\
\hline \multirow[t]{2}{*}{$\begin{array}{l}5 \\
6 \\
7 \\
8 \\
9\end{array}$} & $\begin{array}{r}90 \\
104 \\
98 \\
86 \\
106\end{array}$ & $\begin{array}{l}54 \\
80 \\
70 \\
60 \\
82\end{array}$ & $\begin{array}{r}71(5) \\
88(5) \\
79(3) \\
70(2) \\
105(4)\end{array}$ \\
\hline & $96 \cdot 8: 8 \cdot 7$ & $69 \cdot 2 \div 12 \cdot 2$ & $82 \cdot 6 \div 14 \cdot 5$ \\
\hline
\end{tabular}

*Time studied after nephrectomy shown in parentheses.

after operation is shown in table II. All nine donors had a reduced clearance, averaging $70^{\circ}$, , soon after nephrectomy, but all subsequently improved, so that two to six years later the four men had a mean 24-hour creatinine clearance which was $87 \%$ of their prenephrectomy performance; the five women achieved a mean clearance of $85^{\circ} \%$ in a similar period.

Details of inulin clearance, endogenous creatinine clearance, and glucose reabsorption during infusion as well as 24-hour creatinine clearance are given in table III. Creatinine clearance measured under infusion conditions gives essentially similar results to inulin clearance in all cases $(r=0.94)$. The differences are so small as to be within the errors of the method. Twenty-four hour creatinine clearance is generally credited with overestimating GFR but our data often give results in the opposite direction. ${ }^{1}$

TABLE III-Detailed results in 18 subjects studied

\begin{tabular}{|c|c|c|c|c|c|}
\hline \multirow[b]{2}{*}{$\begin{array}{c}\text { Subject } \\
\text { No }\end{array}$} & \multirow[b]{2}{*}{ 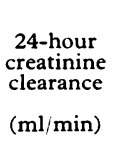 } & \multirow[b]{2}{*}{$\begin{array}{c}\text { Creatinine } \\
\text { clearance } \\
(\mathrm{ml} / \mathrm{min})\end{array}$} & \multicolumn{3}{|c|}{ Infusion data } \\
\hline & & & $\begin{array}{l}\text { Inulin } \\
\text { clearance } \\
(\mathrm{ml} / \mathrm{min})\end{array}$ & $\begin{array}{l}\text { Plateau } \\
\text { plasma } \\
\text { glucose } \\
(\mathrm{mmol} / \mathrm{l})\end{array}$ & \begin{tabular}{|c|} 
Glucose \\
reabsorption \\
("\% filtered \\
load)
\end{tabular} \\
\hline \multicolumn{6}{|c|}{ Male donors } \\
\hline $\begin{array}{l}1 \\
2 \\
3 \\
4\end{array}$ & $\begin{array}{l}84 \\
81 \\
97 \\
89\end{array}$ & $\begin{array}{r}96 \\
111 \\
104 \\
93\end{array}$ & $\begin{array}{r}96 \\
104 \\
97 \\
98\end{array}$ & $\begin{array}{c}7 \cdot 88 \\
8 \cdot 99 \\
12 \cdot 4 \\
12 \cdot 9\end{array}$ & $\begin{array}{l}92 \\
93 \\
76 \\
84\end{array}$ \\
\hline \multicolumn{6}{|c|}{ Female donors } \\
\hline $\begin{array}{l}5 \\
6 \\
7 \\
8 \\
9\end{array}$ & $\begin{array}{r}71 \\
88 \\
79 \\
70 \\
105\end{array}$ & $\begin{array}{l}78 \\
61 \\
93 \\
66 \\
93\end{array}$ & $\begin{array}{l}70 \\
63 \\
85 \\
63 \\
98\end{array}$ & $\begin{array}{l}16 \cdot 9 \\
15 \cdot 5 \\
9 \cdot 16 \\
15 \cdot 4 \\
14 \cdot 7\end{array}$ & $\begin{array}{l}64 \\
63 \\
90 \\
73 \\
71\end{array}$ \\
\hline \multicolumn{6}{|c|}{ Male controls } \\
\hline $\begin{array}{l}10 \\
11 \\
12 \\
13\end{array}$ & $\begin{array}{l}106 \\
118 \\
102 \\
102\end{array}$ & $\begin{array}{l}101 \\
108 \\
104 \\
110\end{array}$ & $\begin{array}{r}87 \\
111 \\
85 \\
111\end{array}$ & $\begin{array}{l}11 \cdot 0 \\
11 \cdot 0 \\
15 \cdot 4 \\
10 \cdot 6\end{array}$ & $\begin{array}{l}88 \\
87 \\
80 \\
79\end{array}$ \\
\hline \multicolumn{6}{|c|}{ Female controls } \\
\hline $\begin{array}{l}14 \\
15 \\
16 \\
17 \\
18\end{array}$ & $\begin{array}{r}86 \\
109 \\
106 \\
128 \\
106\end{array}$ & $\begin{array}{r}82 \\
131 \\
101 \\
152 \\
112\end{array}$ & $\begin{array}{r}77 \\
125 \\
103 \\
140 \\
96\end{array}$ & $\begin{array}{c}13.1 \\
7.99 \\
11.6 \\
6.55 \\
8.99\end{array}$ & $\begin{array}{l}78 \\
98 \\
80 \\
96 \\
97\end{array}$ \\
\hline
\end{tabular}

Conversion: SI to traditional units $-1 \mathrm{mmol} / 1 \approx 18 \mathrm{mg} / 100 \mathrm{ml}$.

For the men GFR, measured by 24-hour creatinine clearance, was higher in those with two kidneys than in those with only one, the difference being statistically significant at the $5^{\circ}$, level. This difference virtually disappeared when GFR was determined by inulin clearance. The male donors could reabsorb glucose as well as the controls.

The performance of women with only one kidney was clearly inferior to that of those with two kidneys. The differences in creatinine clearance, inulin clearance, and glucose reabsorption were significant at the $5 \%$ level (table III). The figure shows clearly the reduced capacity of women with only one kidney to reabsorb glucose.

\section{Discussion}

The GFR in the remaining normal kidney of man is known to increase promptly after contralateral nephrectomy.

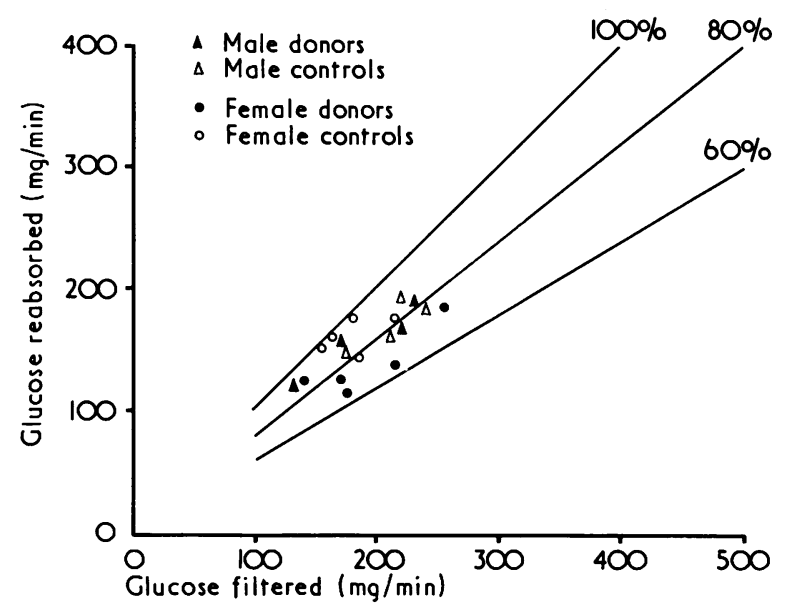

The relation between amount of glucose filtered and amount reabsorbed in 18 subjects. Radiating lines show levels of percentage reabsorption.

Originally it was thought that the increase was complete by seven days but recent work has shown that GFR continues to rise slightly after the initial increment, although the delayed improvement in function is small and inversely related to age. ${ }^{16}$

Using 24-hour creatinine clearance data we have shown that after at least two years one kidney achieves a GFR remarkably close to that of the original two kidneys. After nephrectomy the remaining kidney's proximal convoluted tubules change in response to the increased filtered load. Cellular hypertrophy and hyperplasia occur, in that order, over several weeks. ${ }^{17}{ }^{18}$ In our study the raised GFR had stabilised and the associated tubular compensations were presumably complete.

Obviously prospective studies assessing subjects before and after donor nephrectomy are ideal, and such a study is under way. A study of seven healthy renal donors before and 10-14 days after nephrectomy has already been reported in which several renal indices were examined, ${ }^{5}$ but the renal handling of glucose was studied in only three of the subjects. In that study the sera and urine samples were frozen to await subsequent analysis and there is evidence that precipitation of inulin, particularly from urine, can occur under such conditions. ${ }^{11}$ In addition, the urinary glucose concentration was determined by a glucose oxidase-peroxidase method that underestimates glucose when compared with the hexokinase method, ${ }^{19}$ thus crediting the kidney with a greater reabsorptive capacity than it has. In the pre- and post-nephrectomy studies in these three subjects the classical graph of a fixed maximal tubular reabsorptive capacity for glucose $\left(\mathrm{Tm}_{\mathrm{G}}\right)$ was attained, despite several reports that this entire concept is now difficult to sustain. ${ }^{8} 2021$

The success with which compensatory tubular function occurs after nephrectomy seems to have an obvious sex difference. Judged by the ability to reabsorb a large filtered load of glucose, the male donors showed themselves to be as capable as their controls, but the female donors generally seemed unable to rise to the challenge and were much less efficient than their controls.

Why should the male renal donor be better? Compensatory hypertrophy is directly related to the nitrogen content of the diet, $=2$ and growth hormone, thyroxine, testosterone, and progesterone have renotrophic effects. ${ }^{23}{ }_{24}$ Thus the better end results in the men may have been due to the growth-promoting effects of testosterone on tubules that have the capacity to respond to such stimuli. Damaged tubules may be incapable of responding fully to any stimulus and the question arises whether the widespread occurrence of urinary tract infection, perhaps clinically trivial, in otherwise healthy girls and women may not be a cause. An episode of asymptomatic bacteriuria in childhood or adolescence may be enough to impair proximal tubular function and seems likely to lie behind some pregnant women's grossly reduced ability to reabsorb glucose. ${ }^{3}$ In the context of renal donors it is particularly significant that apparently healthy 
symptom-free relatives of patients with terminal renal disease have an extremely high incidence of underlying renal disease themselves. ${ }^{2 .}: 6$ If such be the case then potential female donors should be investigated rigorously, and some aspect of proximal tubular function should be determined.

We thank the members of the renal transplant team, Newcastle upon Tyne, for their co-operation.

\section{References}

${ }^{1}$ Davison, J M, and Hytten, F E, Fournal of Obstetrics and Gynaecology of the British Commonwealth, 1974, 81, 588.

2 Dunlop, W, British fournal of Obstetrics and Gynaecology, 1976, 83, 17.

${ }^{3}$ Davison, J M, and Hytten, F E, British fournal of Obstetrics and Gynaecology, 1975, 82, 374 .

${ }^{4}$ Bricker, N S, et al, fournal of Clinical Investigation, 1956, 35, 1364.

${ }^{5}$ Pabico, R C, McKenna, B A, and Freeman, R B, Kidney International, $1975,8,166$.

6 Enger, E, Scandinavian fournal of Urology and Nephrology, 1973, 7, 200.

7 Wesson, L G, Kidney International, 1973, 4, 236.

${ }^{8}$ Goldring, W, and Chasis, H, Hypertension and Hypertensive Disease. New York, Commonwealth Fund, 1944.

${ }^{9}$ Davison, J M, and Cheyne, G A, Lancet, 1972, 1, 787.
1" Heyrovsky, A, Clinica Chimica Acta, 1956, 1, 470.

"Robertson, E G, Hytten, F E, and Cheyne, G A, fournal of Obstetrics and Gynaecology of the British Commonwealth, 1970, 77, 1064.

12. Bierans De Haan, J, Reaction Rate Analyser Instruction Manual, London, LKB Limited, 1972.

${ }^{13}$ Schmidt, T H, Der Internist, 1963, 4, 554.

${ }^{14}$ Cheyne, G A, and Yeomans, D L, fournal of Medical Laboratory Technology, 1973, 30, 187.

15 Trinder, O, Annals of Clinical Biochemistry, 1969, 6, 24

${ }^{16}$ Boner, G, et al, American fournal of Medicine, 1973, 55, 169

17 Arrizurieta de Muchuik, E E, Lipham, E M, and Gottschalk, C W, in Compensatory Renal Hypertrophy, ed W W Nowinski and R J Goss. New York, Academic Press, 1969.

${ }^{18}$ McCrory, W W, Developmental Nephrology, Massachusetts, Cambridge, 1972

${ }^{19}$ Lind, T, Shepherd, M M, and Cheyne, G A, Annals of Clinical Biochemistry, 1971, 8, 213.

2" Kurtzman, N A, and Pillay, V K G, Archives of Internal Medicine, 1973, 131, 901 .

${ }^{21}$ Davison, J M, and Hytten, F E, in Proceedings of a Symposium on Carbohydrate Metabolism in Pregnancy and the Newborn, ed $\mathrm{H}$ W Sutherland and J M Stowers. Edinburgh, Churchill Livingstone, 1974.

2:2 Halliburton, I W, and Thomson, R Y, Cancer Research, 1965, 25, 1882.

23 Jelinek, J, Vesela, H, and Valova, B, Acta endocrinologica, 1964, 46, 352. 4 Goss, R J, Proceedings of the Society for Experimental Biology and Medicine, 1965, 118, 342.

25 Johnston, S M, Nephron, 1972, 9, 371.

${ }^{26}$ Spanos, P K, et al, Lancet, 1974, 1, 645.

\title{
Azathioprine and penicillamine in treatment of rheumatoid arthritis : a controlled trial
}

\author{
H BERRY, S P LIYANAGE, R A DURANCE, C G BARNES, L A BERGER, S EVANS
}

British Medical fournal, 1976, 1, 1052-1054

\section{Summary}

Sixty-five patients, 33 receiving azathioprine and 32 receiving penicillamine, took part in a one-year, singleblind external-observer trial designed to compare the efficacy and toxicity of these two drugs in the treatment of rheumatoid arthritis. By six months there was a significantly greater rise in haemoglobin and fall in erythrocyte sedimentation rate among those receiving penicillamine, and by one year this difference remained only in the increase in haemoglobin levels. Fifteen patients, 10 on azathioprine and 5 on penicillamine, had to stop treatment because of side effects; 90 single side effects occurred, 48 in those on penicillamine and 42 in those on azathioprine. After one year both drugs were similar in efficacy and toxicity, but longer-term trials are needed. Both drugs were effective.

Department of Rheumatology, the London Hospital, London E1 1BB H BERRY, DM, MRCP, senior registrar (now consultant rheumatologist, King's College Hospital, London SE5

S P LIYANAGE, MRCP, DCH, senior registrar (now consultant rheumatologist, Canadian Red Cross Hospital, Taplow)

C G BARNES, MB, MRCP, consultant physician

Department of Statistics, London Hospital, London E1 1BB

$\mathrm{S} \mathrm{J}$ W EVANS, BA, MBCs, supervisor of computer services and honorary lecturer in computer science as applied to medicine

Department of Rheumatology and Rehabilitation, St Mary's Hospital, Colchester

R A DURANCE, MB, MRCP, consultant physician

Department of Radiology, Royal Free Hospital, London

L A BERGER, MRACP, FRCR, consultant radiologist

\section{Introduction}

Azathioprine has a steroid-sparing effect in rheumatoid arthritis ${ }^{1}$ that has been shown to be greater than that obtained with gold." Less progression in joint erosions was also reported in patients treated with azathioprine. ${ }^{1}$ :

Penicillamine, introduced by $\mathrm{Jaffe}^{3}+$ for treating severe rheumatoid arthritis, was later confirmed as an effective agent in a multicentre trial. 5 Subsequently Huskisson et al ${ }^{6}$ reported that results with penicillamine were comparable to those obtained with gold.

Our trial was designed to determine whether there is any demonstrable difference between azathioprine and penicillamine in efficacy or toxicity in the treatment of rheumatoid arthritis.

\section{Methods}

A single-blind external-observer trial was performed at the London Hospital, Notley Hospital, and St Mary's Hospital, Colchester. The trial supervisor $(\mathrm{HB})$, who was aware of the treatment allocation, was responsible for routine management, checking blood tests and urine analysis results, and listing unwanted effects described by the patients. Two blind observers assessed the severity of the disease, the same observer always assessing the same patients (SPL at the London Hospital and RAD at the other centres). In an initial pilot study, their assessments on the same patients correlated closely.

Patient selection-Outpatients at the three centres were admitted to the trial if they were over 18 years old and had definite or classical rheumatoid arthritis, ${ }^{7}$ including a positive latex test result (titre of $1 / 80$ or more) and erosive changes on $x$-ray pictures of the hands or feet, or both. The disease had to be severe enough for the clinician to conventionally consider the use of gold. Those patients already receiving systemic corticosteroids were admitted only when the dosage had been constant for at least six months. Criteria for exclusion were : (a) previous treatment at any time with azathioprine or penicillamine or with gold salts in the previous six months; $(b)$ an abnormally low white cell or platelet count at any time; (c) evidence of renal impairment (raised blood urea or serum creatinine concentrations); and $(d)$ risk of pregnancy. Informed consent was obtained from all patients at the beginning of the trial. 